\title{
Potency of Nuisance Flies as Vector of Coxiella burnetii on Dairy Farms in Ampel and Mojosongo Districts, Boyolali Regency, Middle Java, Indonesia
}

\section{Eko Prasetyo Nugroho ${ }^{1}$, Agus Setiyono ${ }^{2 *}$, Upik Kesumawati Hadi ${ }^{3}$, Wiwin Winarsih ${ }^{2}$, Dwi Astuti $^{4}$}

${ }^{1}$ Graduate School, Animal Biomedical Science Study Program, Faculty of Veterinary Medicine, IPB University, Bogor, Indonesia; ${ }^{2}$ Division of Veterinary Pathology, Faculty of Veterinary Medicine, IPB University, Bogor, Indonesia; ${ }^{3}$ Division of Veterinary Parasitology and Entomology, Faculty of Veterinary Medicine, IPB University, Bogor, Indonesia; ${ }^{4}$ Biology Research Center, Division of Zoology, Indonesian Institute of Sciences, Bogor, Indonesia.

\begin{abstract}
This study aimed to determine the characteristics, distribution and diversity of nuisance flies in dairy farms at Ampel and Mojosongo Districts, Boyolali Regency. The $Q$ fever incidence in dairy cattle and the nuisance flies potency as vectors of $Q$ fever were also examined, considering that previous studies found positive cases of $Q$ fever in 4 beef cattle slaughtered at the Ampel Slaughterhouse, Ampel District, Boyolali Regency. The collection of flies was carried out using the sweep net and the Nzi Trap. A total of 351 nuisance flies were collected, analyzed, and as many as 200 flies were examined by nested-PCR with OMP1, OMP2, OMP3 and OMP4 primer. We also collected and tested milk samples (20 samples) with nested-PCR. The results showed no amplified DNA band ( $437 \mathrm{bp})$ in both milk and fly samples. It indicated that there is no evidence of pathogenic infection causing $Q$ fever in dairy cattle at Boyolali Regency and the nuisance flies have not been shown to act as a vector of C. burnetii.
\end{abstract}

Keywords | C. burnetii, Q fever, Nuisance flies, Dairy cattle, Boyolali regency

Received | May 05, 2021; Accepted | July 30, 2021; Published | September 25, 2021

${ }^{*}$ Correspondence | Agus Setiyono, Division of Veterinary Pathology, Faculty of Veterinary Medicine, IPB University, Bogor, Indonesia; Email: agusse@apps. ipb.ac.id

Citation | Nugroho EP, Setiyono A, Hadi UK, Winarsih W, Astuti D (2021). Potency of nuisance flies as vector of Coxiella burnetii on dairy farms in Ampel and Mojosongo Districts, Boyolali Regency, Middle Java, Indonesia. Adv. Anim. Vet. Sci. 9(11): 1781-1790.

DOI | http://dx.doi.org/10.17582/journal.aavs/2021/9.11.1781.1790

ISSN (Online) | 2307-8316; ISSN (Print) | 2309-3331

Copyright (C) 2021 Nugroho et al. This is an open access article distributed under the Creative Commons Attribution License, which permits unrestricted use, distribution, and reproduction in any medium, provided the original work is properly cited.

\section{INTRODUCTION}

A s one of the centers of dairy farm, Boyolali Regency has several districts with a fairly high number of dairy cattle. Traditional-based dairy farms are spread in several locations in each district. Different environments cause different conditions in each district, influencing the existence of the ectoparasites. Q fever is a type of zoonotic disease caused by Coxiella burnetii (C. burnetii) (Eldin et al., 2017). This bacterium usually infects cattle, goats, sheep, and other ruminant livestock. The transmission of Q fever to humans can cause lesions in the lungs (Eldin et al., 2017). Center for Diseases Control and Prevention (CDC, 2013) explained that C. burnetii belongs to group $\mathrm{B}$, which are dangerous microorganisms with the potential to become biological weapon. Coxiella burnetii is very resistant in the environment and has low dose of infection (Setiyono et al., 2008). Some reports of Q fever in Indonesia occurred in Brahman Cross beef cattle (BX cattle) (14\%) from Australia (Setiyono, 2014), Balinese cattle (6.15\%) (Mahatmi et al., 2007), sheep (31.88\%), and goats (20.18\%) (Setiyono et al., 2008). The incidence of $Q$ fever in dairy cattle in Indonesia has never been reported before.

The existence of ectoparasites causes many economic losses and can disturb the environmental comfort. Ectoparasite population fluctuates depending on the environmental 
factors (Hadi and Koesharto, 2006; Chaiphongpachara et al., 2018). The availability of abundant food sources and favorable environmental conditions (optimal temperature and humidity) can increase the population of ectoparasites as well as the risk of disease transmission (Hadi and Koesharto, 2006). Ectoparasites have limited ability in dealing with environmental stresses but are balanced with large reproductive capacity (Hadi and Koesharto, 2006). Different environments can affect animal diversity and density (Milligan et al., 2009). One species of fly that is specific to the environment, Achoetandrus rufifacies, found in the plains at a very high altitude of $2100 \mathrm{~m}$ above sea level (Tumrasvin and Shinonaga, 1978).

C. burnetii can be transmitted through ectoparasite vectors such as flies, ticks, and fleas. Some studies report that $C$. burnetii DNA was found in several species of ectoparasites such as Stomoxys calcitrans, Lucilia coeruleiviridis, L. sericata (Nelder et al., 2008), Hyaloma aegyptium larvae (Siroky et al., 2010), Ctenocephalides felis and Xenopsylla cheopis (Loftis et al., 2006). Nuisance flies as ectoparasites can potentially be a transmission factor of $C$. burnetii. An initial exploration study of $Q$ fever in Boyolali Regency was performed by detecting $C$. burnetii using immunohistochemistry (IHC) in beef cattle organs (liver, lung, spleen, kidney and heart). The study found that 4 out of 100 (4\%) cattle were immunoreactive on the spleen (Nugroho et al., 2021). The purpose of this study was to determine the species diversity, distribution, potency of nuisance flies as a vector of $C$. burnetii and $\mathrm{Q}$ fever incidence in dairy cattle at Boyolali Regency. The results of this study are expected to provide knowledge about the characteristics of nuisance flies and their potential as vectors in Boyolali Regency, as a consideration for the prevention and control of this disease.

\section{MATERIALS AND METHODS}

\section{COLLECTION OF FLY AND MILK SAMPLES}

In this study, 200 flies were examined by nested-PCR and 151 flies for identification. We also collected 20 milk samples for nested-PCR. Fly and milk samples were obtained from several dairy farms at Ampel and Mojosongo District, Boyolali Regency. The samples were collected on 31 January - 5 February 2019.

Fly collection was carried out on dairy farms in three villages at Ampel and Mojosongo Districts. The fly sampling method referred to the modified method of Putra (2016). Flies were collected using a sweep net inside the cowshed on 5 different places. Outside of the cowshed, Nzi traps were installed in several places. A total of 20 milk samples $(20 \mathrm{~mL} /$ individual) were also collected.

\section{Collection sites}

In this study, we collected samples of ectoparasites and milk in 3 villages in Ampel and Mojosongo District, respectively. Ampel District is an area located near the slopes of Mount Merapi (838 masl) with a cold climate. Mojosongo District is located lower (383 masl) than Ampel District. The geographic coordinates of the study sites are shown in Table 1.

Table 1: Geographical coordinates of study site in Ampel district and Mojosongo District, Boyolali Regency.

\begin{tabular}{|c|c|c|c|}
\hline Region & Latitude & Longitude & $\begin{array}{l}\text { Altitude } \\
\text { (masl) }\end{array}$ \\
\hline Ampel District & $7^{\circ} 27^{\prime} 01^{\prime \prime S}$ & 11031'18”E & 838 \\
\hline Banyuanyar Village & $7^{\circ} 28^{\prime} 44^{\prime \prime S}$ & $110^{\circ} 33^{\prime} 20^{\prime \prime} \mathrm{E}$ & 651 \\
\hline Sidomulyo Village & $7^{\circ} 28^{\prime} 31^{\prime \prime S}$ & $110^{\circ} 34^{\prime} 37^{\prime \prime E}$ & 531 \\
\hline Tanduk Village & $7^{\circ} 28^{\prime} 10^{\prime \prime S}$ & $110^{\circ} 33^{\prime} 18^{\prime \prime E}$ & 643 \\
\hline Mojosongo District & 7³2’23”S & $110^{\circ} 36^{\prime} 32^{\prime \prime E}$ & 383 \\
\hline Dlingo Village & $7^{\circ} 30^{\prime} 42^{\prime \prime S}$ & $110^{\circ} 38^{\prime} 43^{\prime \prime} \mathrm{E}$ & 278 \\
\hline Mojosongo Village & $7^{\circ} 32 ’ 21 ” S$ & $110^{\circ} 36^{\prime} 51^{\prime \prime E}$ & 352 \\
\hline Singosari Village & $7^{\circ} 35^{\prime} 03^{\prime \prime S}$ & $110^{\circ} 35^{\prime} 07^{\prime \prime} \mathrm{E}$ & 411 \\
\hline
\end{tabular}

FLY PROCESSING AND IDENTIFICATION

The flies were killed using chloroform in the killing jar. Preservation was carried out by pinning the fly's body with a needle perpendicularly. The needle was inserted into the thoracic part slightly to the right or left side of the centerline. Smaller sized flies could not be pinned. The fly was first attached to triangular paper by glue, then the triangular paper was pinned with a needle (Hadi et al., 2011b). Flies were then identified using key of identification of flies according to Tumrasvin and Shinonaga (1978) to find out the species. Density analyzes of fly populations were carried out for relative abundance, dominance, frequency and diversity index (Wilhm and Doris, 1986).

\section{NeSTED POLYMERASE CHAIN REACTION EXAMINATION}

Milk and fly samples were extracted using the QIAmp DNA mini kit extraction protocol (Qiagen ${ }^{\circledR}$, Germany). The positive control used was pure culture extraction of C. burnetii strain Nine mile (Setiyono et al., 2005), and the negative control was distilled water. Milk samples had been extracted in 4 stages out of a total of 20 samples. In each stage, 5 milk samples were extracted. The extraction of pooled fly samples has already been carried out on a total of 200 samples of flies in 4 stages. There were 50 samples of flies extracted at each stage.

DNA amplification was performed by nested-PCR (nestedPCR). The DNA sample was amplified on a thermal cycler machine (Gene Amp PCR systems 9600, PerkinElmer ${ }^{\circledR}$, USA). The first-round PCR was programmed for 35 cycles. It consisted of pre-denaturation $\left(94^{\circ} \mathrm{C}, 3\right.$ 
minutes), denaturation $\left(94^{\circ} \mathrm{C}, 1\right.$ minute), annealing $\left(54^{\circ} \mathrm{C}\right.$, 1 minute), extension $\left(72^{\circ} \mathrm{C}, 2\right.$ minutes), final extension $\left(72^{\circ} \mathrm{C}, 4\right.$ minutes) and cooling $\left(4^{\circ} \mathrm{C}, \infty\right)$. The first-round PCR product was 501 bp (OMP1 and OMP2) (Ogawa et al., 2004). The primers used in the PCR test are shown in Table 2 .

DNA amplification in nested-PCR was programmed for 35 cycles. It started with pre-denaturation $\left(94^{\circ} \mathrm{C}, 3\right.$ minutes), denaturation $\left(94^{\circ} \mathrm{C}, 1\right.$ minute), annealing $\left(56^{\circ} \mathrm{C}\right.$, 1 minute), extension $\left(72^{\circ} \mathrm{C}, 1\right.$ minute 30 seconds), final extension $\left(72^{\circ} \mathrm{C}, 4\right.$ minutes), and cooling $\left(4^{\circ} \mathrm{C}, \infty\right)$. The nested-PCR product was a DNA amplicon of $437 \mathrm{bp}$ length (OMP3 and OMP4) (Ogawa et al., 2004).

\section{ELECTROPHORESIS}

After the amplification process on the PCR machine was completed, electrophoresis was carried out to see the amplification results using electrophoresis gel (Takara Bio ${ }^{\circledR}$, Japan). Electrophoresis reading was visualized as DNA fragments in bands. The visualization of electrophoresis result was examined under UV luminescence and then photographed.

\section{Data ANALYSis}

Analysis of species diversity data was carried out with descriptive statistics expected to describe data on relative abundance (RA), species frequency $(F)$, species dominance (D) and diversity index (H'). The diversity index used is the Shannon-Wiener index (Wilhm and Doris, 1986) that can be used to characterize the relationship of genus-group in the community.

$$
\begin{gathered}
\mathrm{RA}=\frac{N i}{\mathrm{~N}} \times 100 \% \\
\mathrm{~F}=\frac{n i}{\sum \mathrm{C}} \times 100 \% \\
\mathrm{D}=\mathrm{RA} \times \mathrm{CF} \\
\mathrm{H}^{\prime}=-\sum \mathrm{Pi} \ln P i
\end{gathered}
$$

Description; RA= Relative abundance; $N i=$ Number of specific species fly; $\mathrm{N}=$ Number of various species flies caught; $\mathrm{F}=$ Species frequency; $n i=$ Number of a particular species flies caught; $\Sigma \mathrm{C}=$ Number of catches; $\mathrm{D}=$ Species dominance; $\mathrm{CF}=\mathrm{Caught}$ frequency; $\mathrm{H}^{\prime}=$ Shannon-Wiener diversity index; $\mathrm{Pi}=$ The observed proportion of a particular species.

\section{RESULT AND DISCUSSION}

\section{SPECIES DIVERSITY OF NUISANCE FLIES}

Based on this study, the species of flies obtained from two districts in Boyolali Regency are Chrysomya bezziana, Haematobia exigua, Hippobosca equina, Lucilia sericata,
Musca domestica, and Stomoxys calcitrans (Table 3). Many factors can support the species diversity of flies in a region and increase the survival of each fly species in the environment. The landscape affects the suitable habitat for fly species and environment has specific properties that are ideal for certain species (Junqueira et al., 2017; Chaiphongpachara et al., 2018). Abundant food sources, optimal temperature and humidity can increase the number of ectoparasite populations and the risk of disease transmission (Hadi and Koesharto, 2006). Ectoparasites have a large reproductive ability to survive even in extreme environmental stresses (Hadi and Koesharto, 2006). Fly population is affected by light, temperature and humidity (Komariah and Malaka, 2010). Flies are ectoparasites that are fond of light and not active at night. The number of flies will increase at a temperature of $20^{\circ} \mathrm{C}-25^{\circ} \mathrm{C}$ and will decrease at a temperature of $<10^{\circ} \mathrm{C}$ and $>49^{\circ} \mathrm{C}$ with optimum humidity at $90 \%$ (Komariah and Malaka, 2010).

Chrysomya bezziana belongs to the Calliphoridae family (Figure 1A). Generally, this fly has metallic green color. It has a mouth-licker type. This fly potentially causes obligate myiasis because its pre-adult developmental stadium always requires living animal tissue (Wardhana et al., 2018; Chaiphongpachara and Tubsamut, 2019). The habitat is very diverse, ranging from the residential area, the agricultural area, mountains and forests, as long as there are sufficient sources of food (Wardhana et al., 2018). Larvae of these flies can multiply on carcass, litter and rotting tissue (Wall and Shearer, 2001; Spradbery, 2002).
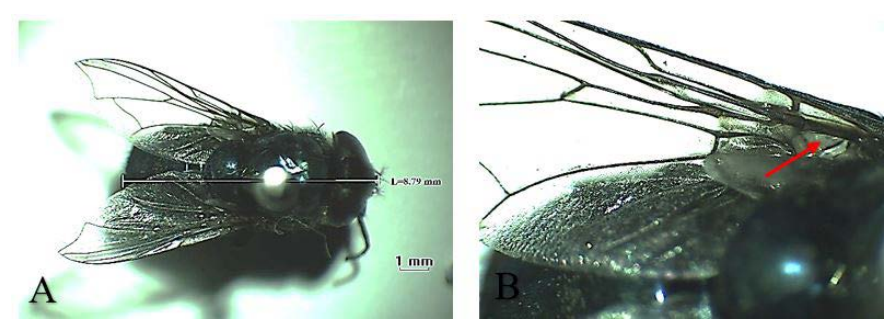

Figure 1: Chrysomya bezziana A. Dorsoventral view; B. Stem vein with bristle (red arrow).
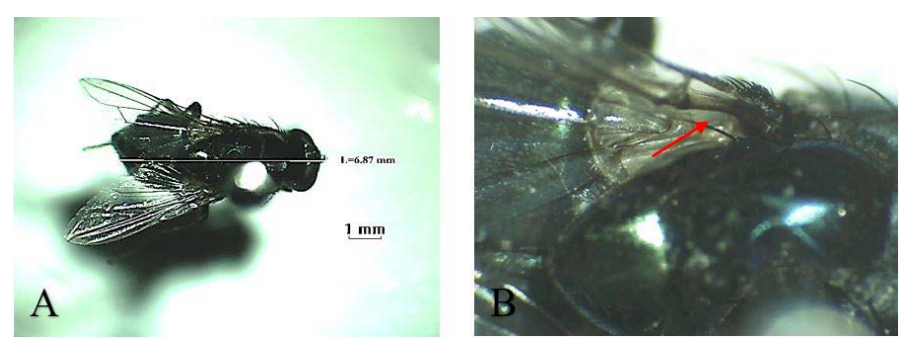

Figure 2: Lucilia sericata; (A) Dorsoventral view; (B) Stem vein without bristle (red arrow).

Lucilia sericata (Figure 2A) is a green fly that commonly found in meat and animal carcasses, and the cause of myiasis in humans and domestic herbivorous animals (Tarone et al., 2011). This fly act as a carrier of some microorganisms 
Table 2: Sequences of oligonucleotides used as primers.

\begin{tabular}{|c|c|c|c|}
\hline PCR & Primer & Sequence & Base pair \\
\hline \multirow[t]{2}{*}{ First Round } & OMP1 & 5- AGT AGA AGC ATC CCA AGC ATT- 3' & \multirow[t]{2}{*}{$501 \mathrm{bp}$} \\
\hline & OMP2 & 5'- TGC CTG CTA GCT GTA ACG ATT- 3’ & \\
\hline \multirow[t]{2}{*}{ Nested } & OMP3 & 5'-GAA GCG CAA CAA GAA GAA CAC-3‘ & \multirow[t]{2}{*}{$437 \mathrm{bp}$} \\
\hline & OMP4 & 5‘-TTG GAA GTT ATC ACG CAG TTG-3‘ & \\
\hline
\end{tabular}

Reference: Ogawa et al., 2004

such as bacteria, viruses and protozoa in humans, causing dysentery, cholera, typhus, diarrhea, and other diseases related to poor environmental sanitary conditions (Tarone et al., 2011). One of the anatomical features of this fly is that the stem veins on its wings do not have bristle (Figure 2B), unlike C. bezziana which has bristle (Figure 1B) (Tumrasvin and Shinonaga, 1978).

Table 3: Number of individual nuisance fly species found in the study site

\begin{tabular}{|llllll|} 
No. Fly species & \multicolumn{2}{l}{ Study site } & Total & $\begin{array}{l}\text { Percent- } \\
\text { age (\%) }\end{array}$ \\
& & $\begin{array}{l}\text { Ampel } \\
\text { district }\end{array}$ & $\begin{array}{l}\text { Mojosongo } \\
\text { district }\end{array}$ & & \\
\hline 1 & C. bezziana & 1 & 2 & 3 & 0.85 \\
\hline 2 & L. sericata & 1 & 0 & 1 & 0.29 \\
\hline 3 & H. exigua & 3 & 53 & 56 & 15.95 \\
\hline 4 & S. calcitrans & 175 & 29 & 204 & 58.12 \\
\hline 5 & M. domestica & 13 & 58 & 71 & 20.23 \\
\hline 6 & H. equina & 0 & 16 & 16 & 4.56 \\
\hline Total & 193 & 158 & 351 & 100 \\
\hline
\end{tabular}

Musca domestica, known as housefly, belongs to the Muscidae family (Figure 3A). The color is gray and it has 4 longitudinal black lines in the dorsal of the thorax. The mouth structure is a mouth-licker type (Figure 3B) that is used for absorbing food (Wall and Shearer, 2001; Sarwar, 2016). Stomoxys calcitrans is a species from the same family as the housefly (Figure 4A). This fly is found in an environment where livestock are caged so that it is known as "stable fly" (Kaufman and Weeks, 2016; Patra et al., 2018). The size of the body is similar to the housefly with a darker color. It has a piercer and sucker-mouth (Figure 4B) to suck the blood of livestock (Wall and Shearer, 2001; Kaufman and Weeks, 2016).

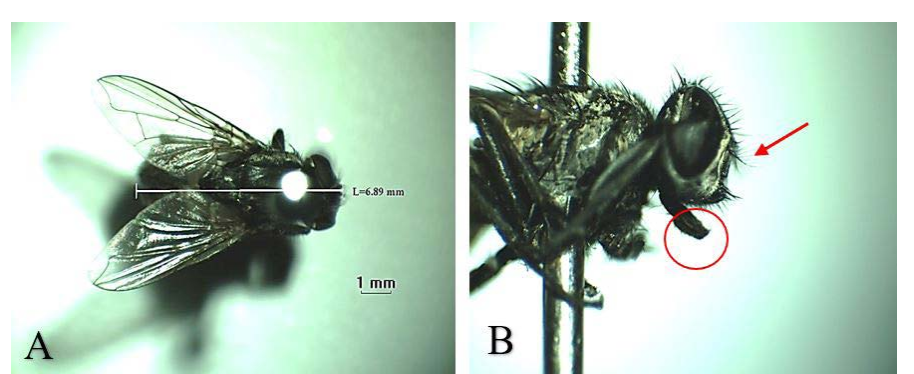

Figure 3: Musca domestica A. Dorsoventral view; B. Arista antennae on dorsal and ventral (red arrows) and licking mouth type (red circle).

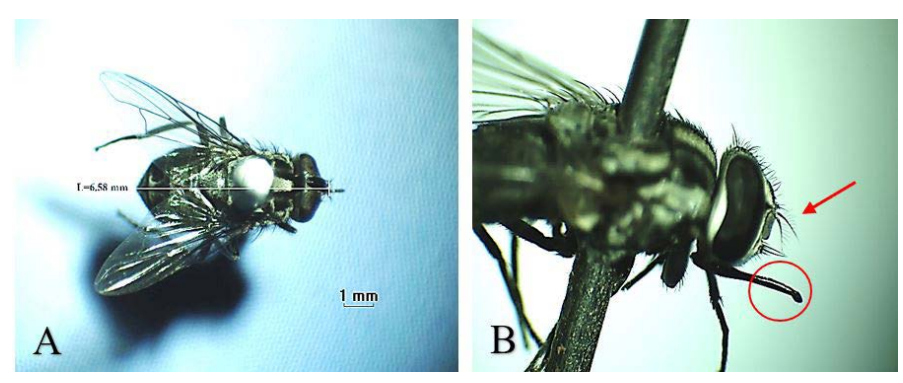

Figure 4: Stomoxys calcitrans (A) Dorsoventral view; (B) Arista antennae only on the dorsal (red arrow) and sucking-piercing mouth type (red circle).
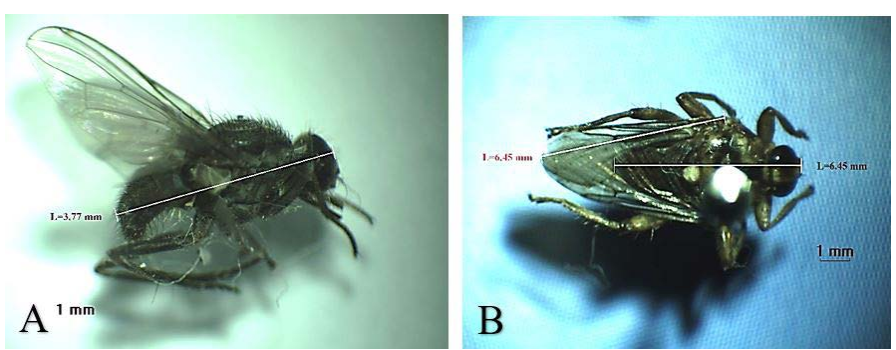

Figure 5: (A) Haematobia exigua lateral view; (B) Hippobosca equina dorsoventral view.

Another fly found is H. exigua (Figure 5A). In Indonesia, this fly is found in farm areas with ranch system. It is also called a horn fly because it swarms a lot around the horns of livestock (Macqueen and Doube, 1988; Iwasa and Ishiguro, 2010). The presence of this fly indicates that the availability of water in the area is limited. Adult fly actively sucks blood during the day causing restlessness to the animals resulting in weight and milk production loss. This fly is an obligate ectoparasite because it is always on the body of its host both for meal and rest (Macqueen and Doube, 1988; Iwasa and Ishiguro, 2010).

The last species of fly found was H. equina (Figure 5B). This fly is an ectoparasite that attacks animals, especially cattle and horses. In Indonesia, this fly is also called Sumba Fly. This fly rarely flies, only creeps on the surface of the body of the host. Generally, both male and female flies suck blood and rest on the host during the day. This fly prefers to settle long on the body of its host and is not easily disturbed by external stimuli. The most preferred areas of this fly are the jugular, perineal and between the hind legs (Turner and Mann, 2004). Hippobosca sp. is a fly that is commonly found in tropical areas with low rainfall and high temperatures, such as in eastern Indonesia, especially 
East Nusa Tenggara and West Nusa Tenggara (Wall and Shearer, 2001). According to Hadi and Soviana (2010) the species of Hippobosca sp. found in Indonesia are H. equina (small Sumba fly) and $H$. variegata (large Sumba fly). This fly was found in Boyolali Regency, allegedly carried by cattle from eastern Indonesia. Livestock traffic is one of the risk factors that play a role in the spread of ectoparasite vectors.

\section{Relative abundance, Species frequency, Species} DOMINANCE AND DIVERSITY INDEX OF NUISANCE FLIES The data of relative abundance, species frequency, species dominance and diversity index of nuisance flies obtained in two districts in Boyolali Regency are shown in Table 4. Hadi et al. (2011a) explained that relative abundance is divided into five categories: very low $(<1 \%)$, low $(1-10 \%)$, medium (10-20\%), high (20-30\%) and very high (>30\%). The relative abundance is the ratio of the number of individual fly species to the total number of individual fly species caught at the study site and expressed in percent (Trianto et al., 2020). The highest relative abundance in Ampel District is S. calcitrans (90.67\%). M. domestica (36.71\%) and H. exigua (33.54\%) have very high relative abundance in Mojosongo District, while $S$. calcitrans (18.5\%) had a medium relative abundance. The relative abundance and high number of flies at the study site were caused by environmental conditions that were conducive to the life of flies such as available breeding places, temperature, sunlight, humidity, texture, and preferred surface color for resting places (Trianto et al., 2020). Flies usually breed in dirty and smelly places such as livestock manure, garbage, organic material, and sewers (Trianto et al., 2020).

The number of fly species frequency is the ratio between the number of fly species caught and the number of catches (Trianto et al., 2020). Frequency value of $S$. calcitrans and $M$. domestica is 1 in two districts which means these flies are always obtained at each catch. Hadi et al. (2011b) explained that the frequency value closer to 1 means that the fly is almost always found at every catching.
Species dominance is the product of the relative abundance and fly frequency of a particular species (Trianto et al., 2020). The highest dominance rate of nuisance fly species obtained in Ampel District is S. calcitrans (90.67\%). Ampel District is one of the districts with the highest number of dairy populations in Boyolali Regency. It causes S. calcitrans domination in this region. This is in line with Afriyanda et al. (2019) and Patra et al. (2018) which explain that the dominant fly in dairy farm is $S$. calcitrans. The dominance factor of fly species is very important to determine the potency of flies as vectors of disease transmission in an environment (Trianto et al., 2020). Flies carrying disease agents that have a high dominance number are very important to be studied deeper. High species dominance indicates that the species has the potential to transmit diseases to animals and humans (Trianto et al., 2020).

In Ampel District, this fly is mostly found outside of the cowshed (Table 5). The environment around the cowshed in this district is dominated by plantations, especially weeds. This is the main habitat of these flies when resting (Kaufman and Weeks, 2016). Phasuk et al. (2013) reported that in both summer and rainy seasons, Stomoxys activity occurs from 10:00 and reaches its peak at 15:00. Masmeatathip et al. (2006) also reported that on beef cattle farms, Stomoxys spp. activity reaches its peak from 14.00 to 16.00 . Afriyanda et al. (2019) also reported that the activity of this fly reaches its peak at $14.00-16.00$ in dairy farms. Kaufman and Weeks (2016) explained that stable fly is diurnal, feeding on their hosts during the early morning and late afternoon in warm weather and the middle of the day in cooler weather. The collection process was carried out in the morning from 08:00 to 10:00, thus causing these flies to be found more outside the cowshed (Table 5). The activity of these flies is still low in the morning. In addition, these flies are also found inside the cowshed, on the body of cattle and piles of feed. Poor hygiene and sanitation systems cause these flies to breed properly. Manure and animal feed waste are ideal breeding sites for this fly (Kaufman and Weeks, 2016; Patra et al., 2018).

Table 4: Relative abundance, Species frequency, Species dominance and Diversity index of nuisance flies Ampel and Mojosongo Districts, Boyolali Regency (January 31-February 5, 2019).

\begin{tabular}{lllllllll} 
Fly Species & \multicolumn{2}{l}{ Relative Abundance (\%) } & \multicolumn{2}{c}{ Species Frequency } & \multicolumn{2}{l}{ Species Dominance (\%) } & \multicolumn{2}{c}{ Diversity Index (H') } \\
& A & B & A & B & A & B & A & B \\
C. bezziana & 0.52 & 1.27 & 0.33 & 0.67 & 0.17 & 0,84 & 0.027 & 0.055 \\
L. sericata & 0.52 & 0.00 & 0.33 & 0.00 & 0.17 & 0,00 & 0.027 & 0 \\
H. exigua & 1.55 & 33.54 & 0.67 & 1.00 & 1.04 & 33.54 & 0.065 & 0.366 \\
S. calcitrans & 90.67 & 18.35 & 1.00 & 1.00 & 90.67 & 18.35 & 0.089 & 0.311 \\
M. domestica & 6.74 & 36.71 & 1.00 & 1.00 & 6.74 & 36.71 & 0.181 & 0.368 \\
H. equina & 0.00 & 10.13 & 0.00 & 0.67 & 0.00 & 6.75 & 0 & 0.232 \\
Total & 100 & 100 & & & & & 0.389 & 1.332
\end{tabular}

Description: A: Ampel District; B: Mojosongo District; H': Shannon-Wiener diversity index. 
Table 5: Fly Distribution in Ampel District (January 31-February 5, 2019).

\begin{tabular}{llllllll} 
Fly Species & \multicolumn{2}{c}{ Banyuanyar Village } & \multicolumn{2}{c}{$\begin{array}{c}\text { Location } \\
\text { Sidomulyo Village }\end{array}$} & \multicolumn{2}{c}{ Tanduk Village } \\
& Inside & Outside & Inside & Outside & \multicolumn{2}{c}{ Inside } & Outside \\
C. bezziana & 0 & 1 & 0 & 0 & 0 & 0 & 1 \\
L. sericata & 0 & 0 & 0 & 0 & 0 & 1 & 1 \\
H. exigua & 0 & 0 & 0 & 1 & 0 & 2 & 3 \\
S. calcitrans & 7 & 49 & 4 & 60 & 5 & 50 & 175 \\
M. domestica & 4 & 1 & 3 & 1 & 2 & 2 & 13 \\
H. equina & 0 & 0 & 0 & 0 & 0 & 0 & 0 \\
Total & 11 & 51 & 7 & 62 & 7 & 55 & 193
\end{tabular}

Table 6: Fly distribution in Mojosongo District (January 31-February 5, 2019).

\begin{tabular}{llllllll} 
Fly Species & \multicolumn{2}{c}{} & \multicolumn{3}{c}{$\begin{array}{c}\text { Location } \\
\text { Dlingo Village }\end{array}$} & \multicolumn{3}{c}{ Mojosongo Village } & \multicolumn{3}{c}{ Singosari Village } \\
& Inside & Outside & Inside & Outside & Inside & Outside \\
C. bezziana & 0 & 1 & 0 & 1 & 0 & 0 & 2 \\
L. sericata & 0 & 0 & 0 & 0 & 0 & 0 & 0 \\
H. exigua & 15 & 1 & 15 & 2 & 18 & 2 & 53 \\
S. calcitrans & 1 & 13 & 1 & 6 & 1 & 7 & 29 \\
M. domestica & 3 & 20 & 2 & 19 & 3 & 11 & 58 \\
H. equina & 10 & 0 & 0 & 0 & 6 & 0 & 16 \\
Total & 29 & 35 & 18 & 28 & 28 & 20 & 158
\end{tabular}

Different results were found in Mojosongo District, $M$. domestica (36.71\%) and H. exigua (33.54\%) dominate this region. H. exigua is more commonly found inside cowshed (Table 6). This fly is found on the body of cattle. M. domestica is more commonly found outside the cowshed. The most preferred places of this fly is the manure disposal and the animal feed waste. Sarwar (2016) explained that housefly is commonly found on livestock manure, feed waste and fermenting vegetable as its breeding sites and feed source. Besides raising dairy cattle, the community in Mojosongo District also raises beef cattle, goats and chickens. Some breeders also have quail farms. The diversity of livestock causes the variation of nuisance flies that dominate this area. H. exigua is more commonly found in dry regions and thrives in warmer climates (Iwasa and Ishiguro, 2010). The life cycle of the fly from eggs, larvae, pupae to adults requires supportive conditions. Optimum temperature and humidity maximize the life cycle of the fly in the environment (Iwasa and Ishiguro, 2010).

The species diversity was measured by using the ShannonWiener diversity index $\left(\mathrm{H}^{\prime}\right)$. The diversity index criteria is divided into 3 categories: 1) H'< 1: low diversity; 2) $1<$ $\mathrm{H}^{\prime}<3$ : moderate diversity; and 3) $\mathrm{H}^{\prime}>3$ : high diversity (Wilhm and Doris, 1986). The value of the diversity index in Ampel and Mojosongo Districts is shown in Table 4. Ampel District has a low diversity index value because based on diversity index analysis, the value is $0.389\left(\mathrm{H}^{\prime}<\right.$ 1). The low variance index means that the diversity of nuisance fly species in Ampel District is not much, 90.67\% is dominated by $S$. calcitrans. The breed of livestock raised is relatively homogeneous. The livestock raised in this area are mostly Friesian Holstein. Mojosongo District has a moderate diversity index value (H': 1.332). Types of flies that dominate in this region are more diverse, that are $M$. domestica, H. exigua and S. calcitrans. Livestocks raised in this region is more varied. In addition to dairy cattle, there are goats, sheep, chickens and quails. The variety of livestock breeds contributes to diverse breeding sites and feeding sources of the fly so that the competition between the flies is relatively low (Sarwar, 2016). Based on geographical conditions, it is known that Mojosongo District has lower elevation than Ampel District. It leads to the higher species diversity in Mojosongo District. Maaz et al. (2018) explained that the abundance of ectoparasites will decrease in line with increasing land fragmentation associated with modernization and population movement. Therefore, the diversity of nuisance fly species in Mojosongo District is relatively more varied because this area is close to Boyolali District which is more developed and modern. Boyolali and Mojosongo Districts are densely populated residential development areas, so these two districts are relatively more advanced than other districts. 
Hygiene and sanitary conditions also affect the dominance of flies. Dairy farms in Boyolali Regency are traditional so the hygiene sanitation practice varies between the breeders. There are several cowsheds found merged with the residential house. The cattle manure disposal system is poor, even many breeders just throw the manure on the empty yard around the cowshed. Patra et al. (2018) explained that poor hygiene and sanitation conditions affect the presence of various species of flies that can potentially spread various diseases.

The role of ectoparasites in animal and human life has been widely known and the losses caused are also very diverse. Ectoparasites that live on the surface of the skin and between host hairs cause irritation, itching, inflammation, and myiasis (Hadi et al., 2011a). This condition causes an uncomfortable feeling that can reduce the nutritional status and productivity of the livestock. Ectoparasites also often make some people feel fear, disgust and hate towards them (entomophobia) such as cockroaches and flies (Hadi et al., 2011a). For some people who are sensitive, allergic reactions, itching and dermatitis are common. Some ectoparasites such as ticks can even cause paralysis due to the toxins they secrete (tick paralysis) (Hadi et al., 2011a).

Another more dangerous aspect of ectoparasites is their role as vectors of various diseases. For example, mosquitoes do not only irritate the host with their bites, but also can transmit disease agents. Flies also have the potential to spread and transmit various diseases. One of the potential diseases in livestock that is spread by flies is lumpy skin disease (LSD). Lumpy skin disease is a disease caused by Lumpy Skin Disease Virus (LSDV), genus Capripoxvirus, family Poxviridae (Neamat-Allah, 2015; Neamat-Allah and Mahmoud, 2019). Cattle suffering this disease will experience decreased milk production, abortion, infertility and skin damage. In addition, the symptoms that appear in livestock are anorexia and fever at a temperature of 40.5$41.3^{\circ} \mathrm{C}$ (Neamat-Allah and Mahmoud, 2019). Nodules on the skin can develop from few to multiple lesions over time, and these lumps can then coalesce and ulcerate (NeamatAllah and Mahmoud, 2019). Skin examination confirmed the presence of hair follicles of scattered eosinophilic intracytoplasmic inclusion bodies, which are characteristic pathognomonic lesions associated with LSD (NeamatAllah and Mahmoud, 2019).

LSDV infected cattle in early stages revealed leucopenia and immunosuppressive effect, so immunostimulant therapy is required (Neamat-Allah, 2015). In late-stage revealed that hemolytic anemia, leucocytosis, and increase of Creatine phosphokinase serum could aid in diagnosis (Neamat-Allah, 2015). Disturbance in liver and kidney function may also occur. Neamat-Allah and Mahmoud
(2019) explained that buffaloes are less susceptible to LSD and suggest that the presence of hypophosphatemia could exaggerate the hemolytic anemia and oxidant-antioxidant imbalance and pro-inflammatory cytokines. The liver, heart, and kidneys could also be affected by LSD infection (Neamat-Allah and Mahmoud, 2019).

\section{NeSTED-PCR EXAMINATION}

Nested-PCR examination has been done on 20 milk and 200 nuisance fly samples. Nested-PCR examination of milk (Figure 6A) and nuisance fly samples (Figure 6B) showed no DNA bands amplified at $437 \mathrm{bp}$. Figure 6A Nested-PCR examination results of the $4^{\text {th }}$ extraction milk sample; B) nested-PCR examination results of the $4^{\text {th }}$ pooling nuisance fly sample; M (marker); $(+)$ (positive control) C. burnetii strain Nine Mile; (-) (negative control/ aquabidest); S (milk sample); L (fly sample).

The role of ectoparasites as vector agents of $\mathrm{Q}$ fever has been widely studied in various countries. $\mathbf{Q}$ fever transmission between animals can occur through ticks (Ixodidae, Argasidae) and flies (Stomoxys sp., Musca sp.) that act as vectors (Maurin and Raoult, 1999; Eldin et al., 2017). Nelder et al. (2008) reported that there are 5 out of 363 flies collected positive for C. burnetii DNA in the USA. The flies include $S$. calcitrans collected from a barn on a farm (1.8\%), where adult flies feed on animal and human blood, Lucilia coeruleiviridis collected in the trash from elephant dung (16.7\%) and L. sericata collected from carcasses (8.3\%). In addition to ticks on ruminants that have been shown to act as vector agents of $\mathrm{Q}$ fever, it has been experimentally reported that the Hyalomma aegyptium larvae can also act as a vector of $C$. burnetii between mammalian host, and a long-term carrier of $C$. burnetii, including transtadial transmission (Siroky et al., 2010). Loftis et al. (2006) reported that C. burnetii DNA was found in PCR examination of Ctenocephalides felis and Xenopsylla cheopis.

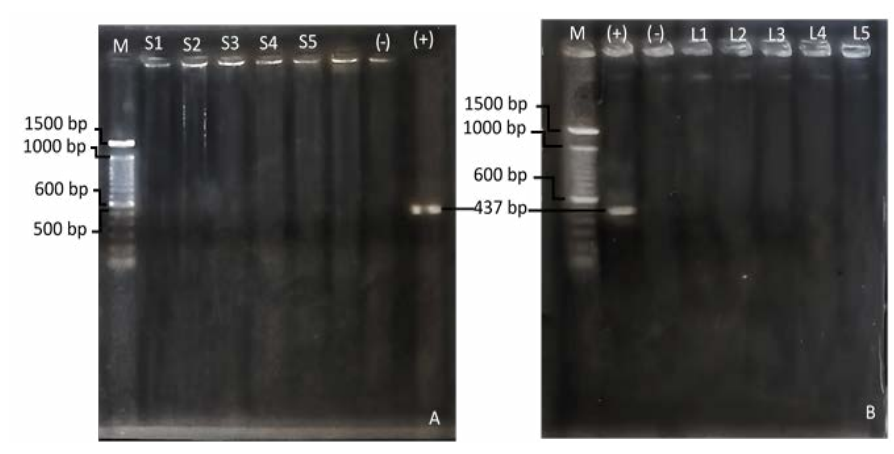

Figure 6: (A) Nested-PCR examination results of the $4^{\text {th }}$ extraction milk sample; (B) nested-PCR examination results of the 4th pooling nuisance fly sample; $\mathrm{M}$ (marker); (+) (positive control) C. burnetii strain Nine Mile; (-) (negative control/ aquabidest); S (milk sample); L (fly sample). 
Some flies feed on various sources such as feces, milk, carcasses, or the blood of pets infected with C. burnetii. The flies regurgitate and defecate while eating, so they are the mechanical vectors of some bacteria (Nayduch et al., 2002). Flies have been shown to transport $C$. burnetii mechanically, and even support the growth of this bacteria. Experimentally, $M$. domestica is known to act as a mechanical vector for $C$. burnetii because this bacteria can survive for 32 days inside the body, 80 days in feces, and 90 days in the carcass (Hucko, 1984). Studies on the presence of C. burnetii in flies collected from the field have never been reported in Indonesia. Therefore, this study is expected to give information about the role of the nuisance fly as a $C$. burnetii transmission factor.

Studies on the incidence of $\mathrm{Q}$ fever in dairy cattle have been widely reported in several countries. Boroduske et al. (2017) reported in Latvia that $10.7 \%$ of cattle milk tested by RT-PCR contained C. burnetii DNA and $13.2 \%$ of dairy cattle tested with ELISA were positive for anti-C. burnetii antibodies. Cattle with abortus in Latvia were also tested and found that $13.4 \%$ were positive for anti-C. burnetii antibodies (Boroduske et al., 2017). The trade of dairy cattle between regions lead to the increase of this disease's transmission Boroduske et al. (2017). Nusinovici et al. (2015) also reported $8.2 \%$ of dairy cattle in southern Sweden were positive for C. burnetii antibodies. Gazyagci et al. (2011) reported as many as 40 dairy cattle (seroprevalence: $12.4 \%$ ) were positive of $\mathrm{Q}$ fever in Konya Province, Turkey.

Kusumawati (2012) reported that as many as 50\% of imported dairy cattle from Australia entering through Soekarno-Hatta airport, Indonesia, were seropositive for Q fever but no C. burnetii DNA was detected using the nPCR method. Fretz et al. (2007) stated the detection limit of C. burnetii using nPCR method on food of animal origin are namely $10^{3}$ cells per $1 \mathrm{~mL}$ of cattle or sheep milk, $10^{2}$ cells per $1 \mathrm{~mL}$ of goat's milk, and $10^{2}$ cells per $15 \mathrm{mg}$ of egg yolk. Thus, further research using serological methods is needed to determine the status of $Q$ fever infection in dairy cattle in Boyolali Regency.

Nugroho et al. (2021) previously reported that there was 4 of 100 (4\%) beef cattle Q fever positive by IHC at Boyolali Regency. Our study indicates that there is no presence of C. burnetii DNA in the nuisance fly's body. It is suspected that flies collected from dairy farms in Boyolali Regency do not transmit C. burnetii. It is supported by the negative result of nPCR test for $C$. burnetii on milk samples from dairy cattles in Boyolali Regency.

\section{CONCLUSIONS AND RECOMMENDATIONS}

The nuisance flies found on dairy farms in Ampel and
Mojosongo districts are Chrysomya bezziana, Haematobia exigua, Hippobosca equina, Lucilia sericata, Musca domestica, and Stomoxys calcitrans. Dairy cattle in Boyolali Regency are suspected to have not been infected with $\mathrm{Q}$ fever. Generally, the livestock raised in Boyolali Regency is homogeneous. The number of beef cattle farms is relatively less than dairy farms. The location of the farms is also far from one another because they are still traditional and not concentrated in one area. The diversity of nuisance flies found in the 2 districts does not necessarily increase the chance of $\mathrm{Q}$ fever transmission but also raises an awareness of controlling fly population at a harmless level. Further study and a wider regional survey are recommended to support our results.

\section{ACKNOWLEDGEMENTS}

This study is one part of the projects funded and sponsored by The Indonesian Ministry of Education and Culture (formerly known as The Indonesian Ministry of Research and Higher Education).

\section{NOVELTY STATEMENT}

The novelty of this study is the data of species diversity, dominance, frequency and distribution of nuisance flies in a dairy farm, Boyolali Regency, Central Java. This is one of the basics for controlling nuisance fly populations that have potential as zoonotic vectors of $Q$ fever.

\section{AUTHOR'S CONTRIBUTION}

The novelty of this study is the data of species diversity, dominance, frequency and distribution of nuisance flies in a dairy farm, Boyolali Regency, Central Java. This is one of the basics for controlling nuisance fly populations that have potential as zoonotic vectors of $Q$ fever.

\section{CONFLICT OF INTEREST}

The authors have declared no conflict of interest.

\section{REFERENCES}

-Afriyanda W, Hadi UK, Soviana S (2019). Ragam jenis dan aktivitas menghisap darap lalat Stomoxys spp. di peternakan sapi perah di Kabupaten Bogor. Acta Vet. Indonesiana, 7(1): 37-45. https://doi.org/10.29244/avi.7.1.37-45

- Boroduske A, Trofimova J, Kibilds J, Papule U, Sergejeva M, Rodze I, Gratina-Ievina L (2017). Coxiella burnetii (Q fever) infection in dairy cattle and associated risk factors in Latvia. Epidemiol. Infect., 145(10): 2011-2019. https://doi. org/10.1017/S0950268817000838

- Centers for Disease Control and Prevention (2013). Diagnosis and management of $Q$ Fever. Georgia (US): National center for infectious diseases, division of viral and rickettsial 
diseases, viral and rickettsial zoonoses branch, Atlanta.

- Chaiphongpachara T, Laojum S, Jongvisuttisan N, Tubsamut P, Dasom A (2018). A checklist of medically important flies (order: diptera) in the central region of Thailand. Biodiversitas, 19(6): 2134-2139. https://doi.org/10.13057/ biodiv/d190620

- Chaiphongpachara T, Tubsamut P (2019). Geometric morphometry of pupae to identify four medically important flies (order: diptera) in Thailand. Biodiversitas, 20(6): 15041509. https://doi.org/10.13057/biodiv/d200603

-Eldin C, Melenotte C, Mediannikov O, Ghigo E, Million M, Edouard S, Mege JL, Maurin M, Raoult D (2017). From $Q$ fever to Coxiella burnetii infection: A paradigm change. Clin. Microbiol. Rev. Am. Soc. Microbiol., 30(1): 116-190. https://doi.org/10.1128/CMR.00045-16

- Fretz R, Schaeren W, Tanner M, Baumgartner A. 2007. Screening of various foodstuffs for occurence of Coxiella burnetii in Switzerland. Int. J. Food Microbiol., 116: 414418. https://doi.org/10.1016/j.ijfoodmicro.2007.03.001

- Gazyagci S, Aktas MS, Kilic S, Babur C, Celebi B, Duru SY (2011). Seroprevalence of $Q$ fever in dairy cattle in the Konya province, Turkey. Rev. Med. Vet., 162(8-9): 387-390.

-Hadi UK, Gunandini DJ, Soviana S, Sigit SH (2011a). Panduan identifikasi ektoparasit: Bidang medis dan veteriner. Bogor (ID): IPB Press.

- Hadi UK, Koesharto FX (2006). Nyamuk. Hama Pemukiman Indonesia Pengenalan, Biologi, dan Pengendalian. Ed: Hadi UK and Sigit SH. Bogor (ID): IPB Press.

-Hadi UK, Soviana S (2010). Hama ektoparasit: Pengenalan, identifikasi, dan pengendaliannya. Bogor (ID): IPB Press.

- Hadi UK, Soviana S, Tatty S (2011b). Ragam jenis nyamuk di sekitar kandang babi dan kaitannya dalam penyebaran Japanese Encephalitis. J. Vet., 12(4): 326-334. https://ojs. unud.ac.id/index.php/jvet/article/view/4231

- Hucko M (1984). The role of the house fly (Musca domestica L.) in the transmission of Coxiella burnnetii. Folia Parasitologica. (Praha). 31: 177-181. PMID: 6745799. https://pubmed. ncbi.nlm.nih.gov/6745799/

-Iwasa M, Ishiguro N (2010). Genetic and morphological differences of Haematobia irritans and $H$. exigua, and molecular phylogeny of Japanese Stomoxyni flies (Diptera, Muscidae). Med. Entomol. Zool., 61(4): 335-344. https:// doi.org/10.7601/mez.61.335

- Junqueira ACM, Ratan A, Acerbi E, Drautz-Moses DI, Premkrishnan BNV, Costea PI, Schuster SC (2017). The microbiomes of blowflies and houseflies as bacterial transmission reservoirs. Sci. Rep., 7(1): 16324. https://doi. org/10.1038/s41598-017-16353-x

-Kaufman PE, Weeks ENI (2016). Stable fly Stomoxys calcitrans (L) (insecta: diptera: muscidae). IFAS Extension. pp. 1-6. https://edis.ifas.ufl.edu/publication/IN1114

-Komariah SP, Malaka T (2010). Pengendalian Vektor. Health J. Bina Husada, 6(1): 34-43. https://repository.unsri. ac.id/9450/

-Kusumawati E (2012). Kajian Q fever pada Sapi Perah Impor dari Australia yang masuk melalui Bandar Udara SoekarnoHatta [Thesis]. Bogot (ID): IPB University.

-Loftis AD, Reeves WK, Szumlas DE, Abbassy MM, Helmy IM, Moriarity JR, Dasch GA (2006). Surveillance of Egyptian fleas for agents of public health significance: Anaplasma, Bartonella, Coxiella, Ehrlichia, Rickettsia, and Yersinia pestis. Am. J.Trop. Med. Hyg., 75: 41-48. https://doi.org/10.4269/ ajtmh.2006.75.41
-Maaz D, Krucken J, Blumke J, Richter D, McKay-Demeler J, Matuschka FR, Hartmann S, Samson-Himmelstjema G (2018). Factors associated with diversity, quantity and zoonotic potential of ectoparasites on urban mice and voles. PLoS One, 13(6): 1-32. https://doi.org/10.1371/journal. pone. 0199385

- Macqueen A, Doube BM (1988). Emergence, host-finding and logevity of adult Haematobia irritans exigua de meijere (Diptera: Muscidae). Aust.J.Entomol., 27: 167-174. https:// doi.org/10.1111/j.1440-6055.1988.tb01516.x

- Mahatmi H, Setiyono A, Damayanti RS, Pasaribu FH (2007). Deteksi Coxiella burnetii penyebab $Q$ fever pada sapi, domba dan kambing di Bogor dan Bali. J. Vet., 8(4): 180-187. https://ojs.unud.ac.id/index.php/jvet/article/view/3213

- Masmeatathip R, Ketavan C, Duvallet G (2006). Morphological studies of Stomoxys spp. (Diptera: Muscidae) in Central Thailand. Kasetsart J., (Natl. Sci.). 40: 872-881.https://www. researchgate.net/publication/283608069_Morphological_ studies_of_Stomoxys_spp_Diptera_Muscidae_in_Central_ Thailand

- Maurin M, Raoult D (1999). Q fever. Clin. Microbiol. Rev., 12(4): 518-533. https://doi.org/10.1128/CMR.12.4.518

-Milligan SR, Holt WV, Lloyd R (2009). Impacts of climate change and environmental factors on reproduction and development in wildlife. Philos. Trans. R. Soc. B Biol. Sci., 364(1534): 3313-3319. https://doi.org/10.1098/ rstb.2009.0175

- Nayduch D, Noblet GP, Stutzenberger FJ (2002). Vector potential of houseflies for the bacterium Aeromonas caviae. Med. Vet. Entomol., 16: 193-198. https://doi.org/10.1046/ j.1365-2915.2002.00363.x

- Neamat-Allah ANF (2015). Immunological, hematological, biochemical, and histopathological studies on cows naturally infected with lumpy skin disease. Vet. World, 8(9): 11311136. https://doi.org/10.14202/vetworld.2015.1131-1136

- Neamat-Allah ANF, Mahmoud EA (2019). Assessing the possible causes of hemolytic anemia associated with lumpy skin disease naturally infected buffaloes. Comp. Clin. Pathol., 28: 747-753. https://doi.org/10.1007/s00580-019-02952-9

- Nelder MP, Lloyd JE, Loftis AD, Reeves WK (2008). Coxiella burnetii in wild-caught filth flies. Emerg. Infect. Dis., 14(6): 1002-1004. https://doi.org/10.3201/eid1406.071691

-Nugroho EP, Setiyono A, Hadi UK, Winarsih W, Astuti D (2021). Immunohistochemical detection of Coxiella burnetii in cattle spleen organ from Ampel Slaughterhouse, Boyolali Regency. J. Medik Vet., 4(1): 1-8. https://doi.org/10.20473/ jmv.vol4.iss1.2021.48-55

- Nusinovici S, Frossling J, Widgren S, Beaudeau F, Lindberg A (2015). Q fever infection in dairy cattle herds: increased risk with high wind speed and low precipitation. Epidemiol. Infect., 143(15): 3316-3326. https://doi.org/10.1017/ S0950268814003926

- Ogawa M, Setiyono A, Sato K, Cai Y, Shiga S, Kishimoto T (2004). Evaluation of PCR Assays currently used for Detection of Coxiella burnetii in Japan. Southeast Asian J. Trop. Med. Publ. Health, 35(4): 151-154. https://www. tm.mahidol.ac.th/seameo/2004_35_4/14-3322.pdf

- Patra G, Behera P, Das SK, Saikia B, Ghosh S, Biswas P, Kumar A, Alam SS, Kawlni L, Lalnunpuia C, Lalchhandama C, Bachan M, Debbarma A (2018). Stomoxys calcitrans and its importance in livestock: A review. Int. J. Adv. Agric. Res., 6: 30-37.

-Phasuk J, Tharawoot T, Chanpaisaeng J (2013). Seasonal 
abundance of blow flies (Diptera: Calliphoridae) in three urban parks of Bangkok, Thailand. Kasetsart J., (Natl. Sci.,). 47(6): 828-834. https://www.researchgate.net/ publication/289361647_Seasonal_abundance_of_blow_ flies_Diptera_Calliphoridae_in_three_urban_parks_of_ Bangkok_Thailand

- Putra AK (2016). Ragam jenis dan aktivitas lalat di kawasan usaha peternakan sapi perah Cibungbulang Kabupaten Bogor [thesis]. Bogor (ID): FKH IPB.

- Sarwar M (2016). Life history of housefly Musca domestica Linnaeus (diptera: muscidae), its involvement in diseases spread and prevention of vectors. Int. J. Res. Appl. Natl. Sci., 2(7): 31- 42. https://gnpublication.org > ans > article > download

- Setiyono A (2014). Cellular pathogenesis of query fever in cattle. Glob. Vet., 13(5): 668-671.

- Setiyono A, Handaryani E, Mahatmi H (2008). Seroprevalensi $Q$ fever pada domba dan kambing di wilayah Jawa Barat. J. Ilmu Ternak dan Vet., 13(1): 6166. http://download.garuda.ristekdikti.go.id/article. php? article $=460541 \& \mathrm{vval}=7168 \&$ title $=$ Seroprevalence $\% 20$ of $\% 20 \mathrm{Q} \% 20$ fever $\% 20 \mathrm{in} \% 20$ sheep $\% 20$ and $\% 20$ goat $\% 20$ in\%20West\%20Java\%20area

- Setiyono A, Ogawa M, Cai Y, Shiga S, Kishimoto T, Kurane I (2005). New criteria for immunoflourescence assay for Q fever diagnosis in Japan. J. Clin. Microbiol., 43(11): 55555559. https://doi.org/10.1128/JCM.43.11.5555-5559.2005

- Siroky P, Kubelova M, Modry D, Erhart J, Literak I, Spitalska E, Kocianova E (2010). Tortoise tick Hyalomma aegyptium as longterm carrier of $Q$ fever agent Coxiella burnetii evidence from experimental infection. Parasitol. Res., 107: 1515-1520. https://doi.org/10.1007/s00436-010-2037-1

- Spradbery JP (2002). A manual for the diagnosis of screw-worm fly. Departement of Agriculture Fisheries and Forestry Australia. pp. 1-59.

-Tarone AM, Picard CJ, Spiegelman C, Foran DR. (2011). Population and temperature effects on Lucilia sericata (Diptera: Calliphoridae) body size and minimum development time. J. Med. Entomol., 48(5): 1062-1068. https://doi.org/10.1603/ME11004

- Trianto M, Marisa F, Siswandari NP (2020). Relative abundance, frequency and dominance of flies in several traditional market at Martapura District. Metamorfosa J. Biol. Sci., 7(2): 163171. https://doi.org/10.24843/metamorfosa.2020.v07.i02. p04

-Tumrasvin W, Shinonaga S (1978). Studies on medically important fies in Thailand. 32 species belonging to the subfamilies Muscinae and Stomoxyinae including the taxonomic keys (Diptera:Muscidae). Bull. Tokyo Med. Dent. Univ., 25(4): 201-207. https://pubmed.ncbi.nlm.nih. gov/282017/

- Turner CR, Mann DJ (2004). Recent observations of Hippobosca equina L. (diptera: hippoboscidae) in South Devon. Br. J. Entomol. Natl. History, 17: 37-40. https:// www.researchgate.net/publication/285056258_Recent_ observations_of_Hippobosca_equina_L_Diptera_ Hippoboscidae_in_south_Devon

-Wall R, Shearer D (2001). Veterinary ectoparasites: Biology, pathology, and control, $2^{\text {nd }}$ edition. Iowa (US): Blackwell Science Ltd. https://doi.org/10.1002/9780470690505

-Wardhana AH, Abadi I, Cameron MM, Ready PD, Hall MJR (2018). Epidemiology of traumatic myiasis due to Chrysomnya bezziana in Indonesia. J. Ilmu Ternak dan Vet., 23(1): 45-60. https://doi.org/10.14334/jitv.v23i1.1617

-Wilhm JL, Doris TC (1986). Biologycal parameter for water quality criteria. BioScience, pp. 447-481. 